\title{
Novatel: The Impact of Leadership Style on the Development of a Chameleon Business Model and Firm Performance
}

\author{
Francisco Javier Leon-Cannock (Corresponding author) \\ School of Education, University of the Incarnate Word \\ 15150 Blanco rd. Apt. 9217, San Antonio, Texas 78232, USA
}

Tel: 1-210-379-5334 E-mail: fleoncan@student.uiwtx.edu

Received: June 7, 2012 Accepted: July 16, 2012 Published: December 1, 2012

doi:10.5296/bms.v3i2.2909 URL: http://dx.doi.org/10.5296/bms.v3i2.2909

\begin{abstract}
This study explores the influence of Novatel's leadership style on the development of the firm's business model. The purpose of this research is to explain the role of this leadership type in the process of creating a business model that both constantly adapts to fit the needs of an ever-changing industry in a highly technological world, and aims to generate innovation and sustainability. In order to analyze this phenomenon, the researcher utilized qualitative methodologies to identify the patterns and themes to be studied. Data interpretation, and its implications, was obtained by using data triangulation and contrasting it with an in-depth review of the literature. Data analysis shows that Novatel's leadership style has both a positive impact within the firm's work dynamic, and suggests a meaningful relationship between the company's leadership style and the formation of a chameleon business model. This business model actively counteracts a fast-paced environment with an ever evolving business strategy. This study is significant because it links the firm's type of leadership to the development of a particular business model and demonstrates how this influences firm performance.
\end{abstract}

Keywords: Leadership, Business model, ICT industry 


\section{Introduction}

Research suggests that there is not one way to define leadership. However, specialists agree that leadership has three fundamental elements: it is a group phenomenon; it is goal directed, and it assumes hierarchy in the group (Nahavandi, 2009). Further research explores the role of entrepreneurial leadership and how it can be linked to firm change, development, innovation, and, consequently, sustainability (Michaclides \& Kardasi, 2010; Kuratko \& Hodgetts, 1989; Light, 1997). These studies also infer that entrepreneurial leaders fit the category of the neo-charismatic/participatory leadership type, which promotes a dynamic, proactive, team-oriented approach to the business endeavor. This initiates collective entrepreneurship within the firm rather than using subordinates as mere instruments of the company (Bass, 1985). Because individual and collective entrepreneurship is not only promoted, but also rewarded, this leadership style encourages employees to assume responsibilities on their own. Thus, this study explores how this particular leadership style defines a firm's business model.

Research in business, economics, and post-modern philosophy suggests that in order to be competitive in today's high-tech, fast-paced world it is necessary to quickly adapt to environmental changes. Business models that do not adapt die (Brown, 1993). Thus, within this theoretical context, this case study focuses on Novatel, a small private Information Communication Technology (ICT) firm in San Antonio, Texas. The purpose of this research is to explore the influence of Novatel's leadership style on the creation of the firm's business model; a model that is constantly being redefined to generate innovation and sustainability.

\section{Novatel: A Multifaceted Leadership Style}

There is not one way to define leadership. Specialists in the field have come up with multiple ways to conceptualize it as they each study different aspects of it (Nahavandi, 2009). Some see leadership as a critical component of the group dynamic (Green \& Mitchell, 1979) and others as an influence process (Bass, 1960; Navahandi, 2009). Others are interested in leadership as an initiating factor (Homans, 1950) and still others as a tool to achieve success (Greenleaf, 1998).

In spite of the theoretical distinctions, researchers agree there are three common fundamental elements: First, that leadership is a group phenomenon; second, that leadership is goal directed; and third, that leadership assumes hierarchy within the group (Nahavandi, 2009). Nahavandi (2009) says, “... by combining these three elements, we can define a leader as any person who influences individuals and groups within an organization, helps them establishing goals, and guides towards achievement of those goals." (pp.4)

Understanding the direct correlation between leadership and change is critical as research shows that leadership is typically linked to change (Michaclides \& Kardasi, 2010). At the same time, entrepreneurs have long been seen as the source of development and innovation (Michaclides \& Kardasi, 2010; Kuratko \& Hodgetts, 1989; Light, 1997). Research suggests that leaders with entrepreneurial minds mobilize the resources of the 
firm with the purpose of initiating high levels of involvement that ultimately generate innovation and sustainability (Michaclides \& Kardasi, 2010; Brazel \& Herbert, 1999; Howell \& Higgins, 1990; Morris \& Jones, 1990; Jelinek \& Litter, 1995; Gupta, McMillan $\&$ Surie, 2004; Graen \& Uhl-Bein, 1995).

Innovation has been critical to Novatel's sustainability. As mentioned above, Novatel began in Mexico because there was a clear opportunity to make excel in the telecommunications industry. Later, Novatel had to adapt to the changes in the industry as it transitioned from a hardware based business model to a software business model (P. Golibart, personal interview, February 10, 2012). This conjuncture opened the door to a new business opportunity: The call center. And, India had the perfect field to play the game. Novatel's only foreign based employee is from India. During an interview at Novatel's headquarters, Employee A (this study will refer to all interviewees as "employees", with the exception of CEO Paul Golibart, and will not disclose names as that information is not relevant to the purpose of the study) was asked about Novatel's presence in India. He said, "We are the biggest U.S. firm doing this business in India. We have over one hundred call centers and we are amongst the most competitive..." (Employee A, personal interview, February 10, 2012).

According to Michaclides and Kardasi (2010) based on Gupta et al.'s (2004) theory, some of the most important components for leadership within the framework of entrepreneurship are to: (1) Articulate a compelling vision; (2) Face organizational change; (3) Initiate personal commitment from the personnel. The research suggests that entrepreneurial leaders with the characteristics mentioned above fall within the category of neo-charismatic/transformational leadership, which focuses on a proactive, team-oriented approach aimed at initiating super-ordinance performance rather than serving as mere instruments to the firm dynamic (Bass, 1985).

Although the research is divided, studies suggest that a CEO's charismatic leadership style can have a significant impact on a firm's performance (Wang, Tsui, \& Xin, 2011). The study of charisma as a fundamental part of leadership theory has dramatically evolved over the past three decades. Nahavandi (2009) suggests that since it began in the 1970's researchers have increasingly included the concept of charisma within the context of organizational development and change as findings reaffirm a direct positive correlation between charisma and company performance.

The newer neo-charismatic, transformational and inspirational leadership style provides several advantages over other leadership models and strategies. First, they look at leaders as inspirational and visionary (Hunt, 1999); they are aware of the importance of followers' emotional responses (Chemers. 1997); and third, according to Nahavandi (2009), "They allow us to understand how leaders create and implement their vision and how they orchestrate and manage large-scale change." (pp. 194). All three are key components to a firm's growth, performance, and sustainability.

Change has been a critical component to Novatel's performance and sustainability. The ICT industry is changing rapidly and firms that do not adapt to this volatile environment 
fail. Golibart says,

"If you are not constantly changing your company fails. This industry changes all the time. We had to change our classification of traffic from international to national. Also, two years ago we went from traditional H323 to WWS (SIP). It is a voice over IP, but the type of package has changed. The industry standard has adapted to the world standard and we had to do it too." (P. Golibart, personal interview, February 10, 2012)

Golibart's charismatic personality is strengthened further by his democratic and participative leadership. This combination of leadership styles can have a significant positive impact within the context of small to medium-sized (SMEs) businesses because it not only delivers an entrepreneurial spirit to the firm's group dynamic, but also generates a collective entrepreneurship in the business (Ribeiro \& Comeche, 2007).

Participative leadership helps the leader motivate and facilitate the participation of employees in the firm's decision making process (Ribeiro \& Comeche, 2007; also see Harber et al., 1991; Cole et al., 1993). In order to have better understanding of Novatel's leadership, CEO Paul Golibart was asked if he would resolve a critical issue related to the firm's most important client on his own or if he would consult with partners and employees to come up with a consensus decision. Golibart said, "Consensus, always" (P. Golibart, personal interview, February 16, 2012). Within the same context of leadership, Novatel's Employee B was asked if he considered the firm's executive receptive to employees' points of view when it came to critical decision making within the context of important business issues. Or, on the contrary, if he thought the company's executive made decisions independently from the opinions of subordinates. Employee B said that Novatel has a very active, dynamic and democratic approach when it came to firm responsibilities and decision making. He says that even though, “... units observe a hierarchy, most decisions are made with input from all members of the unit." (Employee B, personal interview, March 16, 2012).

According to Golibart, Novatel not only promotes employee participation in the firm's business decisions, but also motivates them to do so as the company is made up of a "sweat equity team" (P. Golibart, personal interview, February 15, 2012). Novatel is an Employee Stock Ownership Plan (ESOP), which means the company is owned by the employees. Golibart says, "It is a good management strategy as the employees don't feel entitled (because they didn't invest in the business at inception) and because it incentivizes them to work harder" (P. Golibart, personal interview, February 16, 2012). Novatel's ESOP encourages employees to assume responsibilities on their own by rewarding behaviors that promote innovation (Bowen \& Lawler, 1992: Ribeiro \& Comeche, 2007). These behaviors and how they correlate to the firm dynamic define not only Novatel's business strategy but also the company's business model.

\section{Adapt or die. Redefining business models in today's fast-paced world: A post- modern approach}

It is not easy to be successful in today's competitive and constantly changing business 
world. The logical, structured, detached, and rational approach that characterizes a modern business philosophy is from time to time shattered by non-orthodox entrepreneurs with post-modern tactics. This artistic, non-scientific, method can bring about more creative, intuitive, spontaneous, and far less rigid strategies to the business endeavor (Brown, 1993).

In fact, a non-creative, dinosaur-like, business model is all but doomed to fail, as demonstrated by the fate of the iconic Sears. A company once at the top of the retail industry closed over one hundred stores nationwide in 2011 and is on the verge of bankruptcy (Munarriz, 2011; Schaefer, 2011). Today's high tech, fast paced, environment must be counteracted with an always evolving business strategy. Nevertheless, the biggest problem lies within companies sticking to their old ways and not accepting that while change is a risk, it's also an opportunity to revamp the business. Adapt or die (McCullum, 2001).

True, adapt or die is the motto of savvy businessmen. Smart entrepreneurs are like chameleons, they regularly reshape their business models to generate sustainability (Jansen, Jagers \& Steenbakkers, 2007; Casadeus-Masanell \& Ricart, 2011). During the 1990s companies were fascinated with business models and with the structure and regulation they provided. However, globalization continued in the $21^{\text {st }}$ century, the powers of technology and deregulation have demystified the logical and detached business models of the pre-digital world. These new approaches have replaced the old dinosaurs with innovative, culturally oriented, proactive, and sui generis business models that have changed the industries, redistributed profits, and radically transformed the way business is conducted in the world (Casadeus-Masanell \& Ricart, 2011).

Casadeus-Masanell and Ricart (2011) claim that, "Good business models create virtuous cycles that, over time, result in competitive advantage" (pp.102) Successful entrepreneurs and companies know how to effectively strengthen their virtuous cycles and, throughout that process, turn their competitors' strengths into weaknesses (Casadeus-Masanell \& Ricart, 2011).

Researchers agree that there is not one way to define business models. Furthermore, they concur that business models have to do with organizational design and strategy perspectives (Chandler, 1962; George \& Bock, 2010; Zott \& Amit, 2007). In simple terms, designs and perspectives define what a business does and how efficiently it makes profits in that endeavor (D'Urso, Herman, Weill \& Woerner, 2005).

\section{Chameleons only change colors not shapes: Novatel's business model}

The complexity of today's fast paced, high-tech, globalized world makes industries less of a melting pot and more of a salad bowl (Laubeová, 2000). This phenomenon presents two developments that organizations must face. First, is individualization. Businesses must adapt, tailor and match the demands of individual costumers. Second, the developments in information and communication technology are empowering individuals significantly. Thus, the capacity meet the needs of a growing market of empowered costumers must also increase (Jansen, et al., 2007). 
Golibart describes how Novatel has adapted to the industry throughout the years in order to generate profits:

"In 1997 I saw the opportunity of making 20\% of a nickle per minute in the carrierto-carrier business in Mexico, while I would make $20 \%$ of a cent locally. So, I put my hardware (a CISCO box) in Mexico and started a very profitable business. Over the years, the industry changed and with the development of better software (CISCO boxes were no longer needed in Mexico) it became more profit4able to make business in the US. So, today our business is $95 \%$ local and $5 \%$ international. We see what the market need is and we go for it" (P. Golibart, personal interview, February 16, 2012).

"Novatel is a chameleon," as its own CEO Paul Golibart describes it, because it is a business that has the ability to adapt to the needs of the business environment while remaining the same at the core. Chameleons only change colors not shapes (Jansen, et al., 2007). Golibart says, "At Novatel, sales representatives and managers have been with us from inception. We are the same inside, but the company has changed markets multiple times". According to Golibart, it is central to Novatel's business model to build an efficient customer-relationship management strategy (CRM). An effective CRM gives the company a competitive advantage within the industry, which provides a unique added value to the business (Jansen, et al., 2007)

The study of business models is critical to entrepreneurial practice as it examines business opportunity generation. However, the lack of cohesiveness among the research has resulted in isolated bits of theoretical information, which have produced endless numbers of academic questions on the subject, especially within the scope of entrepreneurship (George \& Bock, 2010). Therefore, designing and implementing an effective business model is imperative for a business' success and sustainability. It is within the context of theoretical ambiguity that the role of leadership can determine the effective setup of a business model as it integrates an articulated vision, makes sense of missions, and determines and communicates high performance objectives (Tsui, Wang \& Xin, 2011).

\section{Methodology and Findings}

\subsection{Purpose}

To explore the influence of Novatel's style of leadership on the formation of the firm's business model. Therefore, explaining how this type of leadership generates a business model that is constantly being redefined to fit the needs of the industry in a highly technological age that aims to generate innovation and sustainability.

\subsection{Methodology}

This case study is qualitative in design. The methodology used by the researcher included interviews, observations, field notes, and company documents. These methodological tools provided the themes to be included in this research. The study's themes and patterns, and their implications, were obtained by using data triangulation and by contrasting it with the review of the literature. 


\subsection{Findings}

The qualitative analysis of the variables using data triangulation and exhaustive review of the literature finds Novatel's leadership style to be entrepreneurial, charismatic and participatory. The analysis also finds this leadership type to have a positive impact in both the firm's internal work dynamic and the company's ability to adapt to the industry's changes-as it encourages internal collective entrepreneurship, innovation, and sustainability. Finally, this study finds that Novatel's adoption of a post-modern business philosophy allowed them successfully adapt to the harsh changes of the telecomunications industry. This study also shows a strong relationship between Novatel's type of leadership and the formation of a chameleon business model.

\subsection{Significance}

This study is significant because it links the impact of a type of leadership to the development of a particular business model and its relationship to firm performance. This demonstrates important practical applications to the process of generating company entrepreneurship, environmental adaptability, and, consequently, business sustainability.

\section{Conclusions and Discussions}

The results obtained from contrasting the literature with the qualitative analysis of the data collected show the impact that Novatel's entrepreneurial, neo-charismatic and participatory leadership style has on the formation of the firm's chameleon business model. Novatel's business model is characterized by constantly redefining itself to meet the needs of a highly complex, ever-changing, ICT industry. The interpretation of the data, within this single instance, finds a significant relationship between Novatel's leadership style, the development of its business model, and firm performance. Thus, this case study's data and interpretations are carefully examined to find themes, issues, and patterns that would further characterize this particular case. This examination not only builds a strong case for this specific phenomenon, but also looks for conclusions that may have applicable implications beyond this research.

\section{References}

Acs, Z. J., Braunerhjelm, P., Audretsch, D. B., \& Carlsson, B. (2009). The knowledge spillover theory of entrepreneurship. Small Business Economics, 32(1), 15-30. http://dx.doi.org/10.1007/s11187-008-9157-3

Bass, B. M. (1985), Leadership and Performance Beyond Expectations, New York: Free Press.

Bass, B.M. (1960). Leadership. psychology, and organizational behavior. New York: Harper and Row.

Bowen, D.E., \& Lawler, E.E. III (1992), “The empowerment of service workers: what, why, how, and when", Sloan Management Review, 33(3), 31-9.

Brazeal, D.V., \& Herbert, T. T. (1999), "The genesis of entrepreneurship", 
Entrepreneurship Theory \& Practice, 23(3), 29-45

Brown, S. (1993) Postmodern marketing? European Journal of Marketing, 27(4), 19.

Casadesus-Masanell, R., \& Ricart, J. E. (2011). How to design A winning business model. Harvard Business Review, 89(1), 100-107.

Chandler, A.D. (1962). Strategy and structure: Chapters in the history of the industrial enterprise. Cambridge, MA: The MIT Press.

Chemers, M. M. (1997). An integrative theory of leadership. Mahwah, NJ: Lawrence Erlbaum.

Cole, R.E., Bacdayan, P. and White, B.J. (1993), "Quality, participation and competitiveness", California Management Review, 35( 3), 68-81.

Dunham, L. C. (2010). From rational to wise action: Recasting our theories of entrepreneurship. Journal of Business Ethics, 92(4), 513-530. http://dx.doi.org/10.1007/s10551-009-0170-5

George, G., \& Bock, A. J. (2011). The business model in practice and its implications for entrepreneurship research. Entrepreneurship: Theory \& Practice, 35(1), 83111.http://dx.doi.org/10.1111/j.1540-6520.2010.00424.x

Graen, G.B., \& Uhl-Bein, M. (1995), "Relationship-based approach to leadership: development of leader-member (LMX) theory of leadership over 25 years applying a multi-domain perspective.” Leadership Quarterly 6(2), 219-247.

Green, S.G., \& Mitchell, T. (1979). Attributional Processes of leaders in leader-member interactions. Organizational Behavior and Human Performance (23), 429-458.

Greenleaf, R.K. (1998). The power of servant leadership. San Francisco, CA: BerretKoehler.

Guerra, H. S. (2009). Effective organisations in the international arena. Pensamiento \& Gestión, (26), 120-136.

Gupta, V., MacMillan, I. C., \& Surie, G. (2004), "Entrepreneurial leadership: Developing and measuring a cross-cultural construct". Journal of Business Venturing 19, 241-250.

Harber, D.; Marriot, F. and Idrius, N. (1991), "Employee participation in TQM: an integrative review", International Journal of Quality \& Reliability Management, 8(5), 2434.

Hench, T. J., PhD. (1999). Rediscovering entrepreneruship in a complex world: A nonlinear framework for organizing. Journal of Business and Entrepreneurship, 11(10426337), 1-X.

Homans, G. C. (1950). The human group. New York: Harcourt, Brace.

Howell, J. M., \& C. A. Higgins (1990), 'Champions of technological innovations', Administrative Science Quarterly, 35(8), 317-41 


\section{Macrothink}

Business Management and Strategy

ISSN 2161-7104

2012, Vol. 3, No. 2

Hunt, J. G. (1999). Transformation/charismatic leadership's transformation of the field: A historical essay. The Leadership Quarterly 10, 129-144.

Jansen, W., Steenbakkers, W., \& Jagers, H. (2007). New business models for the knowledge economy. Hampshire: Gower Publishing Limited.

Jelinek, M. \& Litterer, J.A. (1995), 'Toward entrepreneurial organizations: Meeting ambiguity with engagement', Entrepreneurship Theory and Practice, 19(3), 137-158

JOYCE, P. (2010). Leading and leadership: Reflections on a case study. Journal of Nursing Management, 18(4), 418-424. http://dx.doi.org/10.1111/j.13652834.2010.01090.x

Kautonen, T., van Gelderen, M., \& Tornikoski, E. T. (2013). Predicting entrepreneurial behaviour: A test of the theory of planned behaviour. Applied Economics, 45(6), 697-707. http://dx.doi.org/10.1080/00036846.2011.610750

Kuratko, D. F. \& Hodgetts, R. M. (1989), Entrepreneurship: A Contemporary Approach. Chicago: Driden Press

Laubeova, L. (2000). Melthing pot vs ethnic stew. Encyclopedia of the World's Minorities. Fitzroy Dearborn Publishers.

Light, P.C. (1997), The Tides of Reform: Making Government Work 1945-1995. New Haven: Yale University Press

Lim, B., \& Ployhart, R. E. (2004). Transformational leadership: Relations to the fivefactor model and team performance in typical and maximum contexts. Journal of Applied Psychology, 89(4), 610-621. http://dx.doi.org/10.1037/0021-9010.89.4.610

Lucky, E. O., \& Olusegun, A. I. (2012). Is small and medium enterprises (SMEs) an entrepreneurship? International Journal of Academic Research in Business \& Social Sciences, 2(1), 487-496.

Martinez, C. A., \& Williams, C. (2010). National institutions, entrepreneurship and global ICT adoption: A cross-country test of competing theories. Journal of Electronic Commerce Research, 11(1), 73-91.

McCallum, J. (2001). Adapt or die. Ivey Business Journal. [Online] Available: http://www.iveybusinessjournal.com/

Michaelides, P., \& Kardasi, O. (2010). Sehumpeter's theory of leadership: A brief sketch. Journal of Philosophical Economics, 3(2), 122-133.

Morris, M.II., Jonos, F.F. (1999), "Entrepreneurship in established organizations: The case of the public sector". Entrepreneurship Theory \& Practice, 24(1), 71-91

Munarriz, A. (2011) Is Sears headed to bankruptcy? The Daily Finance. [Online] Available: www.dailyfinance.com

Nahavandi, A. (2009). The art and science of leadership. $5^{\text {th }}$ edition. Upper Saddle River, 
NJ: Prentice Hall.

Nichols, T. W. (2008). Authentic transformational leadership and implicit leadership theories. (Ph.D., University of North Texas). ProQuest Dissertations and Theses, . (MSTAR_304537868)

Noy, E. (2010). Niche strategy: Merging economic and marketing theories with population ecology arguments. Journal of Strategic Marketing, 18(1), 77-86. http://dx.doi.org/10.1080/09652540903511324

Oxford handbook of entrepreneurship / (2006). In Casson M.,1945- (Ed.), . Oxford ; New York: Oxford University Press.

Ribeiro, D., \& Comeche, J.M. (2007). Transmitting the entrepreneurial spirit to the work team in SMEs: the importance of leadership. Management Decision, 45(7), 1102-1122.

Rice, F. H. (1991). In United States. Small Business Administration (Ed.), Marketing strategies for the growing business. Washington, D.C.: Washington, D.C. : U.S. Small Business Administration.

Schaefer, S. (2011). Ho ho no for sears: Store closures coming after weak holiday. Forbes.Com, 4-4.

Taylor, A., Cocklin, C., Brown, R., \& Wilson-Evered, E. (2011). An investigation of champion-driven leadership processes. The Leadership Quarterly, 22(2), 412-433. http://dx.doi.org/10.1016/j.leaqua.2011.02.014

Tondeur, J., Cooper, M., \& Newhouse, C. P. (2010). From ICT coordination to ICT integration: A longitudinal case study. Journal of Computer Assisted Learning, 26(4), 296306. http://dx.doi.org/10.1111/j.1365-2729.2010.00351.x

Wang, H., Tsui, A.S., \& Xin, K.R. (2011): CEO leadership behaviors, organizational performance, and employees' attitudes. The Leadership Quarterly, 22, 92-105.

Weill, P., Malone, T.W., D'Urso, V.T., Herman, G., \& Woener S. (2004). Do some business models perform better than others? A study of the 1000 largest US firms. Massachusetts: MIT Press.

Wind, Y., Mahajan, V., \& Swire, D. J. (1983). An empirical comparison of standardized portfolio models. Journal of Marketing, 47(2), 89.

Yammarino, Francis J.Spangler, William D.Dubinsky,Alan J. (1998). Transformational and contingent reward leadership: Individual, dyad, and group levels of analysis. Leadership Quarterly, 9(1), 27.

Zott, C. \& Amit, R. (2007). Business model design and the performance of entrepreneurial firms. Organization Science, 18(2), 181-199. 